\title{
Nutrient mass balance of the seagrass Posidonia oceanica: the importance of nutrient retranslocation
}

\author{
Teresa Alcoverro*, Marta Manzanera, Javier Romero
}

Departament d'Ecologia, Universitat de Barcelona, Avgda. Diagonal 645, 08028 Barcelona, Spain

\begin{abstract}
The seasonal nutrient mass balance of the dominant seagrass of the Mediterranean, Posidonia oceanica (L.) Delile, was evaluated in NE Spain in order to test the hypothesis that the effect of seasonal nutrient imbalance can be reduced by the reutilization of internal nutrient pools. To this end we investigated the seasonal and age-dependent variability of nitrogen and phosphorus concentration of the leaves, inferring from these data values of seasonal nitrogen and phosphorus incorporation, uptake, losses and retranslocation. Incorporation of nitrogen and phosphorus in leaves peaked in June and was lowest in September, thus following the seasonal growth pattern of the plant. Retranslocation of nitrogen and phosphorus was high from May to September and close to zero during the rest of the year. Losses of nitrogen and phosphorus were highest at the end of summer, associated with the major biomass losses. Nitrogen uptake by leaves reached maximum values in winter and was lowest during August-September, while phosphorus uptake was highest in spring and lowest in August-September. On an annual basis nitrogen and phosphorus uptake accounted for 60 and $41 \%$ of the total nutrient incorporation, respectively, while retranslocation of nutrients from old tissues accounted for the remaining 40 and $59 \%$. Although roots and rhizomes function as sources of nutrients at the beginning of the summer, their contribution to the seasonal nutrient budget seemed to be minor.
\end{abstract}

KEY WORDS: Mediterranean Sea · Phosphorus · Nitrogen · Uptake - Incorporation

\section{INTRODUCTION}

Posidonia oceanica (L.) Delile is the dominant seagrass species of the Mediterranean Sea and one of the most important primary producers in its coastal waters (e.g. Buia et al. 1992). Several factors control the seasonality of the primary production of this seagrass. Large-scale factors such as light and temperature seem to be most important (Alcoverro et al. 1995), while nutrients, even though the Mediterranean is an oligotrophic sea (Poole \& Atkins 1929, Weinberg 1976, Ivanoff 1977), seem to play a secondary role (Alcoverro et al. 1997). However, maintenance of high productivity requires high nutrient incorporation, especially in late spring-early summer, when seagrasses grow fast

\footnotetext{
- Present address: Centre d'Estudis Avançats de Blanes, CSIC, Camí de Santa Bàrbara s/n, 1.7300 Blanes, Girona, Spain. E-mail: teresa@ceab.csic.es
}

and nutrient availability is low (Alcoverro et al. 1995). In terrestrial vegetation, one of the major mechanisms by which plants adjust to nutrient imbalance is by conservation through decreased losses by leaching (Tukey 1970) and by translocation of a large proportion of nutrients from senescing leaves before abscission (Shaver \& Melillo 1984). Both these processes contribute to the high nutrient use efficiency of plants growing under nutrient-limited conditions (Vitousek et al. 1982).

Several authors investigated the chemical elementary composition of the seagrasses (see Duarte 1990). Posidonia oceanica shows high $\mathrm{N}$ concentrations during winter and a decline during spring and summer (Pellegrini 1971, Bay 1978, Pirc 1985, Pirc \& Wollenweber 1988, Alcoverro et al. 1995). The general trend of a decline in nutrient concentration with increasing tissue age (Patriquin 1972, Harrison \& Mann 1975, Thayer et al. 1977. Walker et al. 1989) indicates that nutrients are 
either leached to the external medium or retranslocated from old tissues before these are lost. Nutrient reclamation may be an important mechanism in the annual seagrass nutrient budget (Patriquin 1972, Borum et al. 1989, Pérez-Llorens \& Niell 1989, Hemminga et al. 1991, Pedersen \& Borum 1992, Stapel \& Hemminga 1997). Leaching losses apparently seem low (Borum et al. 1989, Pedersen \& Borum 1992) and most of the nitrogen lost from old tissues is recovered in young leaves.

In this paper, we test the hypothesis that seasonal nutrient imbalance in the seagrass Posidonia oceanica can be alleviated by nutrient conservation. A preliminary attempt to evaluate the role of retranslocation in the nutrient budget of the plant has been done in a previous work (Alcoverro et al. 1997), but was based on a very general leaf mass balance. Here we report results of a much more accurate balance from a totally new dataset, which includes an assessment of the tissue age as a source of variability and an evaluation of the role of below-ground organs. This allows more precise evaluation of nitrogen and phosphorus incorporation, uptake, losses and retranslocation.

\section{METHODS}

The study was conducted in a Posidonia oceanica meadow located in the Medes Islands, NE coast of Spain $\left(42^{\circ} 2^{\prime} \mathrm{N}, 3^{\circ} 13^{\prime} \mathrm{E}\right)$ near the upslope limit of the meadow ( $-5.0 \mathrm{~m}$, see Alcoverro et al. 1995). Every 2 mo (i.e. 7 sampling events, from November 1992 to December 1993), leaf growth was estimated using a modification of the leaf marking technique (Zieman 1974, Romero 1989a). To do this, 10 shoots, distributed at random over an area of ca $100 \mathrm{~m}^{2}$, were marked at each sampling event; all leaves within a shoot had 2 parallel holes punched in them with a hypodermic needle just above the ligula of the outermost leaf. At the same time, shoots marked in the previous visit were collected, and, in the laboratory, 'new' (tissue below the mark) and 'old' tissue were sorted, dried at $70^{\circ} \mathrm{C}$ and weighed to obtain leaf elongation (new tissue, $g$ dry weight $[\mathrm{dw}] \operatorname{shoot}^{-1} \mathrm{~d}^{-1}$ ) and biomass (new + old tissue, $g \mathrm{dw}$ shoot $^{-1}$ ).

At each sampling event, 30 additional shoots were collected at random over an area of ca $100 \mathrm{~m}^{2}$. In the laboratory, epiphytes were removed using a razor blade, and shoots were sorted into different parts as follows: leaf sheaths (only in 5 sampling events), roots, rhizomes and leaf tissue of different ages. Tissue age was considered instead of leaf age due to the longevity of the leaves of Posidonia oceanica, which can include a wide age range, from apex to basal parts. Four age classes were considered: from 0 to $25 \mathrm{~d}$ (A 1), from 25 to
$50 \mathrm{~d}$ (A2), from 50 to $100 \mathrm{~d}$ (A3) and from 100 to $150 \mathrm{~d}$ (A4). Age determination was done according to the leaf growth curves of Romero (1989b) combined with direct data of leaf growth.

All these fractions were dried $\left(70^{\circ} \mathrm{C}\right.$ until constant weight), weighed, ground and analyzed for $\mathrm{C}, \mathrm{N}$ and $\mathrm{P}$ concentrations. Total carbon and nitrogen were determined using a Carlo-Erba CHN Analyzer and phosphorus was determined by induced coupled plasma after wet acid digestion of the material (Mateo \& Sabaté 1993). Since a single shoot did not provide enough material for the element analysis of the photosynthetic tissue, the 30 shoots were randomly sorted into 3 groups of 10 shoots each to ensure adequate replication; each analysis was performed in pooled material from these 10 shoots, resulting in a total of 3 replicates per age class and sampling event. For the rest of the plants (rhizome and roots) 3 to 6 replicated measures were done per sampling event.

For the photosynthetic parts of the plant (leaves), within-shoot yearly nutrient mass balance was computed using $25 \mathrm{~d}$ intervals; nutrient concentration and leaf growth were obtained by linear interpolation between sampled times and sampled age classes. The seasonal trend of both leaf growth and nutrient concentration in leaves seems to be robust enough (Romero 1989b, Alcoverro et al 1995) to allow these interpolations.

Shoot biomass losses were computed as:

$$
B L_{i}=1 / 25\left(B_{i-25}-B_{i}\right)+P_{i}
$$

where $B L_{i}$ are the biomass losses between $i$ and $i-25$ ( $g$ dw shoot ${ }^{-1} \mathrm{~d}^{-1}$ ), $i$ is the time (days) from the beginning of the experiment, $B_{i}$ is the total shoot biomass (as $\mathrm{g} \mathrm{dw}$ shoot ${ }^{-1}$ ) at time $i$ and $P$; is shoot growth between $i-25$ and $i$ (as g dw shoot ${ }^{-1} \mathrm{~d}^{-1}$ ).

The within-shoot tissue age composition was estimated using the following equation:

$$
B_{i j}=B_{i-25, j-1} \text { except for } j=1 \text {, where } B_{i 1}=P_{1} \times 25
$$

and except for those $k(k \leq \mathrm{n})$ verifying

$$
\sum_{j=1}^{k} B_{\eta}>B_{i} \text {. }
$$

for which

and

$$
B_{t k}=B_{i k+1}=\ldots=B_{i n}=0
$$

$$
\begin{aligned}
& B_{i k-1}=B_{1} \bullet-\sum_{j=1}^{k-1} B_{i j} \\
& \text { with } B_{1} \bullet=\sum_{j=1}^{n} B_{l j}
\end{aligned}
$$

where $j$ is the age class in 25 d intervals, $n=6$ being the total number of age classes, $B_{i j}$ is the biomass (as $\mathrm{g} \mathrm{dw}$ shoot $^{-1}$ ) of age class $j$ at time $i$. 
Initial age distribution (for November) was obtained from Romero (1989b).

Assuming that retranslocation of nutrients occurs before loss of leaves take place, nitrogen and phosphorus leaf retranslocations were estimated as:

$$
L R_{j}=1 / 25\left(\sum_{j=1}^{n}\left(C_{i-25, j}-C_{i, j+1}\right) B_{1-25 . j}\right)
$$

where $L R$, is the leaf retranslocation (in $\mathrm{mg}$ element shoot ${ }^{-1} \mathrm{~d}^{-1}$ ) between time $i$ and $i-25$ and $C_{i j}$ is the concentration (as \% relative to $d w$ ) of the given element for the age class $j$ at time $i$.

Nutrient incorporation was estimated as:

$$
N I_{i}=P_{1} \times C_{11}
$$

where $N I_{i}$ is the nutrient incorporation (as $\mathrm{mg}$ element shoot $\mathrm{t}^{-1} \mathrm{~d}^{-1}$ ) between time $i$ and $i-25, P_{i}$ is shoot growth between $i-25$ and $i$ (as g dw shoot ${ }^{-1} \mathrm{~d}^{-1}$ ), $C_{i 1}$ is the element concentration (as \% of dw) at time $i$ of the youngest age class ( 0 to $25 \mathrm{~d}$ ).

Nutrient losses were computed as:

$$
N L_{i}=B L_{1} C_{i j \max }
$$

where $N L_{1}$ are the nutrient leaf losses (as mg element shoot ${ }^{-1} \mathrm{~d}^{-1}$ ) between $i$ and $i-25, B L_{1}$ are the biomass losses (as $\mathrm{g} \mathrm{dw}$ shoot ${ }^{-1} \mathrm{~d}^{-1}$ ) between $i$ and $i-25$ and $C_{\text {ijmax }}$ is the element concentration (as \% relative to $\mathrm{dw}$ ) of the oldest tissue age class which was present at time $i$.

Nutrient uptake per shoot was estimated as:

$$
N U_{i}=N L_{i}+1 / 25\left(\sum_{j=1}^{\mathrm{n}} B_{i j} C_{i j}-\sum_{j=1}^{\mathrm{n}} B_{(j-25) j} C_{(1-25) j}\right)
$$

where $N U_{i}$ is the nutrient uptake (as $\mathrm{mg}$ element shoot ${ }^{-1} \mathrm{~d}^{-1}$ ) between $i$ and $i-25$. This estimate covers total uptake per shoot and, thus, includes both root and leaf uptake.

No such detailed estimate was possible for the below-ground organs (roots and rhizomes), but the possibility of seasonal storage in these organs was evaluated by computing a budget of gains/losses between successive sampling events, as a product of standing biomass multiplied by nutrient concentration change (positive or negative). This approach is reliable in the case of Posidonia oceanica due to the peculiarities of its below-ground biomass. In effect, we assume here that rhizome + root biomass is constant throughout the year (see Cebrián et al. 1997) and equal to the values reported by Mateo \& Romero (1997): $1.16 \mathrm{~g} \mathrm{dw}$ shoot $^{-1}$ for rhizomes and $0.74 \mathrm{~g} \mathrm{dw}$ shoot $^{-1}$ for roots. In addition, we also assume that processes such as nutrient incorporation are modest in relation to total nutrient pools: annual values of nutrient ( $\mathrm{N}$ and $\mathrm{P}$ ) incorporation and losses never exceed $6 \%$ of the total nutrients accumulated in these parts (Mateo \& Romero 1997).
The potential role in the nutrient economy of the other non-photosynthetic plant parts (i.e. leaf bases or petioles) was also investigated using the same approach (mass budget).

Two-way ANOVA was used to partition the variance observed in nutrient concentration (nitrogen, carbon and phosphorus) of leaves into variance among sampling events (time), tissue type ( $A 1$ to $\mathrm{A} 4$ ) and their interaction. One-way ANOVA was performed to assess the variance in leaf sheath nutrient concentration due to differences among sampling events (Sokal \& Rohlf 1981)

\section{RESULTS}

Leaf carbon concentration differed with leaf age (Table 1), with the highest values found in the youngest tissues (A1, Fig. 1a) and the lowest in the old tissue (A4, Fig. 1a). There were also significant differences among sampling events (Table 1), with the highest values observed in December and the lowest in May. However, both factors accounted only for a minor part of total variability (14 and $11 \%$, respectively).

Leaf nitrogen concentration was highly seasonal, with high values observed in winter and low values at

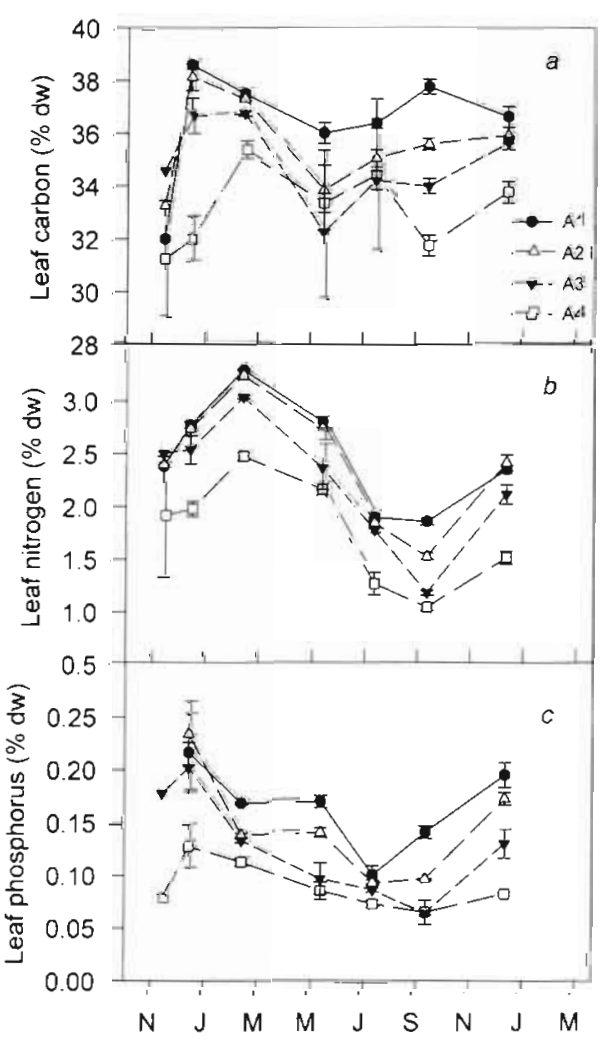

Fig. 1. Changes with time in concentrations of carbon, nitrogen and phosphorus in leaves of different age (as \% of dw). Mean values and standard error 
Table 1. ANOVA table summarizing the significance of the differences found in carbon, nitrogen and phosphorus concentration in leaves among age classes (Tissue) and among sampling events (Time) and in sheaths, rhizomes and roots (only Time factor considered)

\begin{tabular}{|c|c|c|c|c|c|}
\hline Variable & Factor & df & MS & $\mathrm{p}$ & $\%$ variance \\
\hline$\%$ carbon leaves & $\begin{array}{l}\text { Time } \\
\text { Tissue } \\
\text { Time } \times \text { Tissue } \\
\text { Error }\end{array}$ & $\begin{array}{r}6 \\
3 \\
18 \\
83\end{array}$ & $\begin{array}{r}17.3 \\
42.0 \\
5.5 \\
6.8\end{array}$ & $\begin{array}{r}0.026 \\
<0.001 \\
0.684\end{array}$ & $\begin{array}{l}11 \\
14 \\
- \\
-\end{array}$ \\
\hline$\%$ nitrogen leaves & $\begin{array}{l}\text { Time } \\
\text { Tissue } \\
\text { Time } \times \text { Tissue } \\
\text { Error }\end{array}$ & $\begin{array}{r}6 \\
3 \\
18 \\
83\end{array}$ & $\begin{array}{l}4.8 \\
2.25 \\
0.05 \\
0.042\end{array}$ & $\begin{array}{c}<0.0001 \\
<0.0001 \\
0.176\end{array}$ & $\begin{array}{l}72 \\
17 \\
- \\
-\end{array}$ \\
\hline$\%$ phosphorus leaves & $\begin{array}{l}\text { Time } \\
\text { Tissue } \\
\text { Time } \times \text { Tissue } \\
\text { Error }\end{array}$ & $\begin{array}{r}6 \\
3 \\
18 \\
85\end{array}$ & $\begin{array}{l}0.0290 \\
0.0243 \\
0.0017 \\
0.0008\end{array}$ & $\begin{array}{r}<0.0001 \\
<0.0001 \\
0.0150\end{array}$ & $\begin{array}{r}50 \\
21 \\
9 \\
-\end{array}$ \\
\hline$\%$ carbon sheaths & $\begin{array}{l}\text { Time } \\
\text { Error }\end{array}$ & $\begin{array}{r}4 \\
17\end{array}$ & $\begin{array}{l}8.65 \\
1.24\end{array}$ & 0.001 & $\begin{array}{c}62 \\
-\end{array}$ \\
\hline$\%$ nitrogen sheaths & $\begin{array}{l}\text { Time } \\
\text { Error }\end{array}$ & $\begin{array}{r}4 \\
15\end{array}$ & $\begin{array}{l}0.65 \\
0.028\end{array}$ & $<0.0001$ & $\begin{array}{c}86 \\
-\end{array}$ \\
\hline$\%$ phosphorus sheaths & $\begin{array}{l}\text { Time } \\
\text { Error }\end{array}$ & $\begin{array}{r}4 \\
15\end{array}$ & $\begin{array}{l}0.0027 \\
0.0003\end{array}$ & 0.0003 & $\begin{array}{c}71 \\
-\end{array}$ \\
\hline$\%$ carbon rhizome & $\begin{array}{l}\text { Time } \\
\text { Error }\end{array}$ & $\begin{array}{r}6 \\
44\end{array}$ & $\begin{array}{r}11.01 \\
6.15\end{array}$ & 0.123 & - \\
\hline$\%$ nitrogen rhizome & $\begin{array}{l}\text { Time } \\
\text { Error }\end{array}$ & $\begin{array}{r}6 \\
40\end{array}$ & $\begin{array}{l}1.56 \\
0.13\end{array}$ & $<0.0001$ & $\begin{array}{c}62 \\
-\end{array}$ \\
\hline$\%$ phosphorus rhizome & $\begin{array}{l}\text { Time } \\
\text { Error }\end{array}$ & $\begin{array}{r}6 \\
22\end{array}$ & $\begin{array}{l}0.0009 \\
0.0007\end{array}$ & 0.304 & $\begin{array}{l}- \\
-\end{array}$ \\
\hline$\%$ carbon root & $\begin{array}{l}\text { Time } \\
\text { Error }\end{array}$ & $\begin{array}{r}5 \\
21\end{array}$ & $\begin{array}{l}4.95 \\
0.56\end{array}$ & 0.0001 & $\begin{array}{c}68 \\
-\end{array}$ \\
\hline$\%$ nitrogen root & $\begin{array}{l}\text { Time } \\
\text { Error }\end{array}$ & $\begin{array}{r}6 \\
22\end{array}$ & $\begin{array}{l}0.065 \\
0.027\end{array}$ & 0.064 & $\begin{array}{l}- \\
-\end{array}$ \\
\hline$\%$ phosphorus root & $\begin{array}{l}\text { Time } \\
\text { Error }\end{array}$ & $\begin{array}{r}6 \\
14\end{array}$ & $\begin{array}{l}0.0011 \\
0.0003\end{array}$ & 0.027 & $\begin{array}{c}61 \\
-\end{array}$ \\
\hline
\end{tabular}

the end of summer (Fig. 1b, Table 1). Nitrogen concentrations ranged from $3.3 \%$ of dry weight young tissue, $\mathrm{A} 1$, in winter) to $1 \%$ of dry weight (old tissue, A4, in summer). Nitrogen concentrations decreased with tissue age, but the seasonal pattern was similar across age classes (non-significant interaction term). We observed a slightly lower concentration at the end of the sampling period (January 1993) compared to that of the previous year (January 1992) for all 4 age classes.

Phosphorus concentration also showed significant seasonal changes (Table 1), but with the maximum value preceding that of nitrogen (Fig. 1C). The highest values were again found among the youngest tissue (Fig. 1c). Seasonal pattern significantiy but only slightly (see the significant interaction in Table 1) differed in oldest leaves ( $\mathrm{A} 3$ and $\mathrm{A} 4$ ) from youngest ones (A1 and A3).

Carbon concentration in leaf sheaths was lowest in winter and highest in summer (Fig. 2a, Table 1). Con- centrations of nitrogen and phosphorus in the leaf sheaths followed the same trend as in the leaves, although with lower values, and also showed a clear decrease at the end of the second year relative to the equivalent period of the previous year (Fig. 2b,c, Table 1).

Carbon concentration in the rhizomes did not vary among sampling events (Fig. 3a, Table 1). In contrast, nitrogen concentration in the rhizomes did differ between sampling events but there was no seasonal trend. Maximum values were reached in May and December 1993, while the concentration reached in December 1992 was half that found the following year (Fig. 2b). Although the time course of phosphorus concentrations was similar to that of nitrogen (Fig. 3b,c) these differences proved to be non-significant (Table 1 ).

The carbon concentration in roots reached minimum levels in November, and was relatively constant the rest of the year (Fig. 4a). Nitrogen and phosphorus concentrations in the roots showed a common trend 


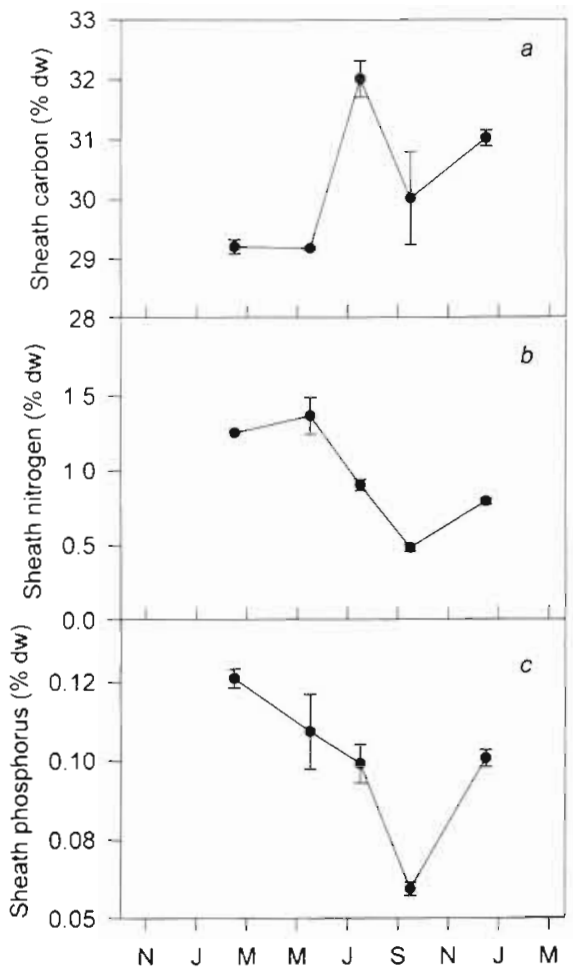

Fig. 2. Changes with time in concentrations of carbon, nitrogen and phosphorus in leaf sheaths (as \% of dw). Mean values and standard error

with 2 peaks, one in November-December and another one in May, although the variation in nitrogen was not significant (Fig. 4b,c, Table 1).

The incorporation of nitrogen and phosphorus in leaves reached a maximum in June and a minimum in September (Fig. 5), thus following the growth pattern of the plant (Table 2). Retranslocation of nitrogen was high from March to September (up to $92 \mu \mathrm{g} \mathrm{N}$ shoot $^{-1}$ $\mathrm{d}^{-1}$ ) while retranslocation of phosphorus was high from January to September (highest value: $4.5 \mu \mathrm{g} \mathrm{Phoot}^{-1}$ $\mathrm{d}^{-1}$ ). Retranslocation of both nutrients was very low during the rest of the year (Fig. 5). Nitrogen and phosphorus losses were highest at the end of summer, associated with the major biomass losses (Table 2, Alcoverro et al. 1995), being more irregular the rest of the year (Fig. 5). Nitrogen uptake reached maximum values in winter (113 $\mu$ g shoot $^{-1} \mathrm{~d}^{-1}$, Fig. 5) and the minimum levels in August-September $\left(0 \mu \mathrm{g} \mathrm{shoot}^{-1} \mathrm{~d}^{-1}\right)$. Uptake of phosphorus was highest in spring and fall (up to $6.1 \mu \mathrm{g} \mathrm{shoot}{ }^{-1} \mathrm{~d}^{-1}$, Fig. 5) while the slowest uptake (close to zero) was found again in late summer (August-September). On an annual basis, nitrogen and phosphorus uptake accounted for 60 and $41 \%$ of the nutrient incorporation, respectively, while retranslocation from old tissues potentially accounted for the remaining $40 \%$ for nitrogen and $59 \%$ for phosphorus (considering leaching close to zero).

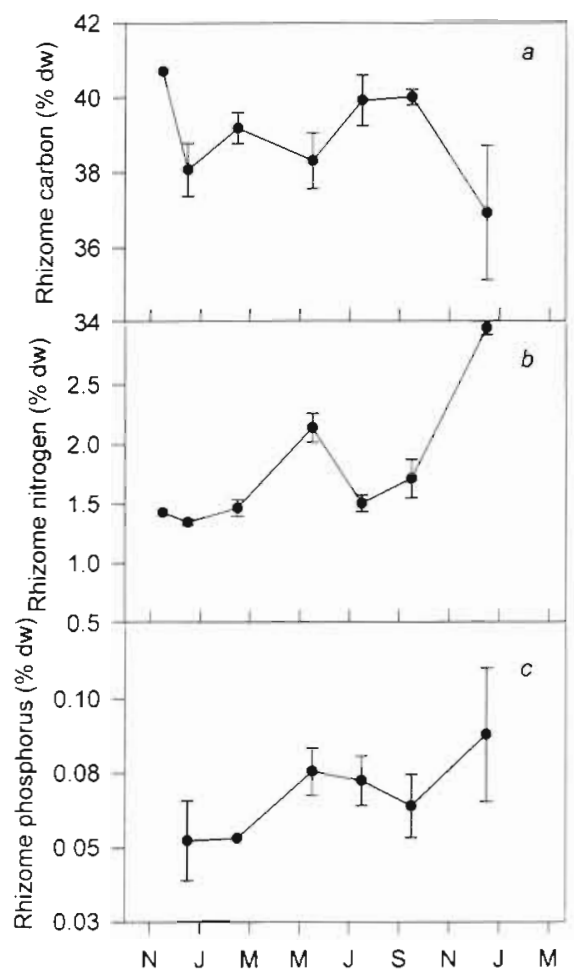

Fig. 3. Changes with time in concentrations of carbon, nitrogen and phosphorus in rhizomes (as \% of $d w$ ). Mean values and standard error

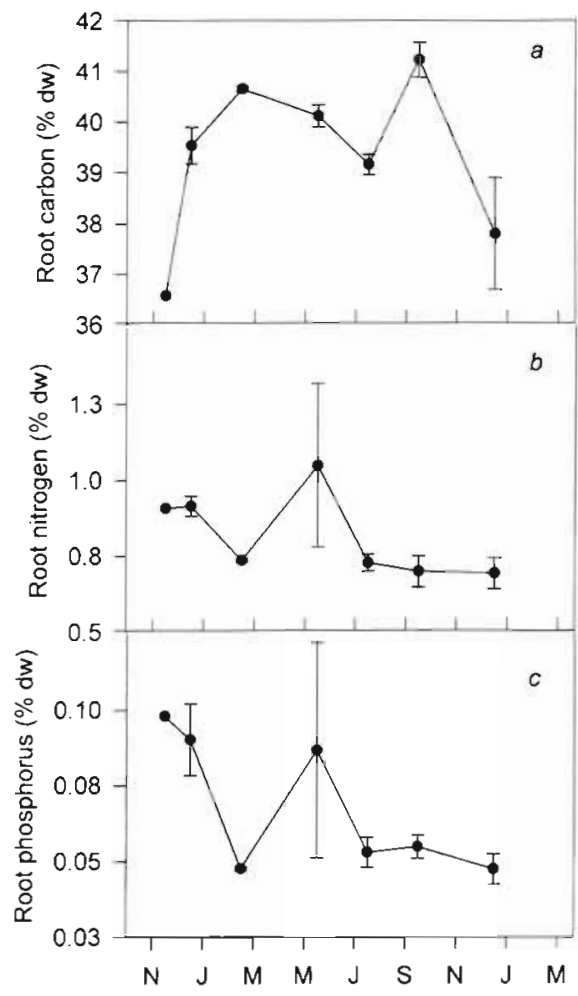

Fig. 4. Changes with time in concentrations of carbon, nitrogen and phosphorus in root (as \% of dw). Mean values and standard error 
Table 2. Leaf biomass, growth and leaf biomass lost during the sampling period. Values represent averages of 10 replicates (standard error). Values without standard error were obtained by linear interpolation (estimation)

\begin{tabular}{|lccc|}
\hline Month & $\begin{array}{c}\text { Shoot biomass } \\
\left.\text { (mg shoot }{ }^{-1}\right)\end{array}$ & $\begin{array}{c}\text { Shoot growth } \\
\left(\mathrm{mg} \mathrm{shoot}^{-1} \mathrm{~d}^{-1}\right)\end{array}$ & $\begin{array}{c}\text { Shoot lost } \\
\left(\mathrm{mg} \mathrm{shoot}^{-1} \mathrm{~d}^{-1}\right)\end{array}$ \\
Nov & $320(15.2)$ & $4.0(0.19)$ & \\
Dec & $340(21.4)$ & $3.8(0.27)$ & 3.13 \\
Jan & 374 estim & 3.5 estim & 2.41 \\
Feb & 442 estim & 3.1 estim & 0.78 \\
Mar & $477(41.3)$ & $2.8(0.31)$ & 1.63 \\
Apr & 510 estim & 4.1 estim & 2.97 \\
May & 578 estim & 5.0 estim & 2.76 \\
Jun & $612(80.0)$ & $7.9(0.64)$ & 6.76 \\
Jul & $858(39.9)$ & $5.0(0.51)$ & -3.2 \\
Aug & $430(39.9)$ & $2.6(0.43)$ & 16.87 \\
Sep & $200(93.8)$ & $2.0(0.21)$ & 9.66 \\
Oct & 238 estim & 2.4 estim & 1.13 \\
Nov & 315 estim & 3.2 estim & 0.63 \\
Dec & $354(33.2)$ & $3.6(0.18)$ & 2.3 \\
\hline
\end{tabular}

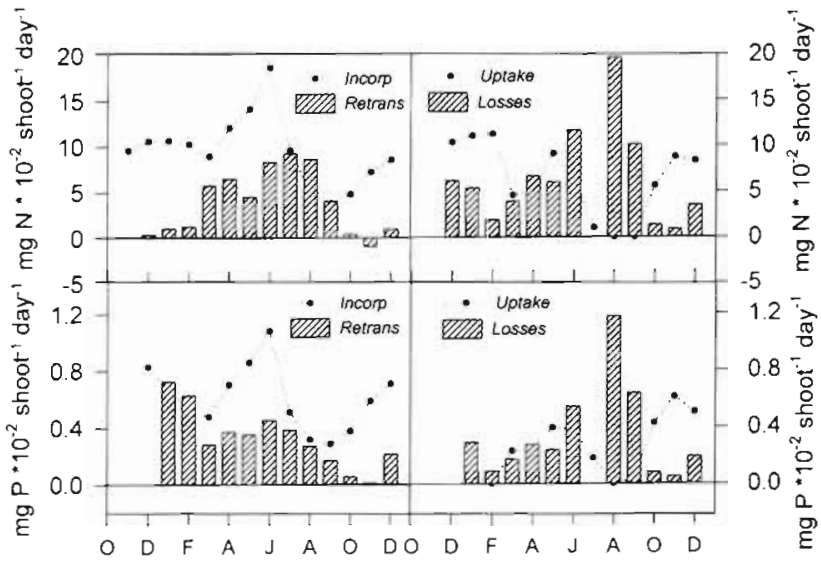

Fig. 5. Changes with time in incorporation, retranslocation, uptake and losses of nitrogen and phosphorus in leaves

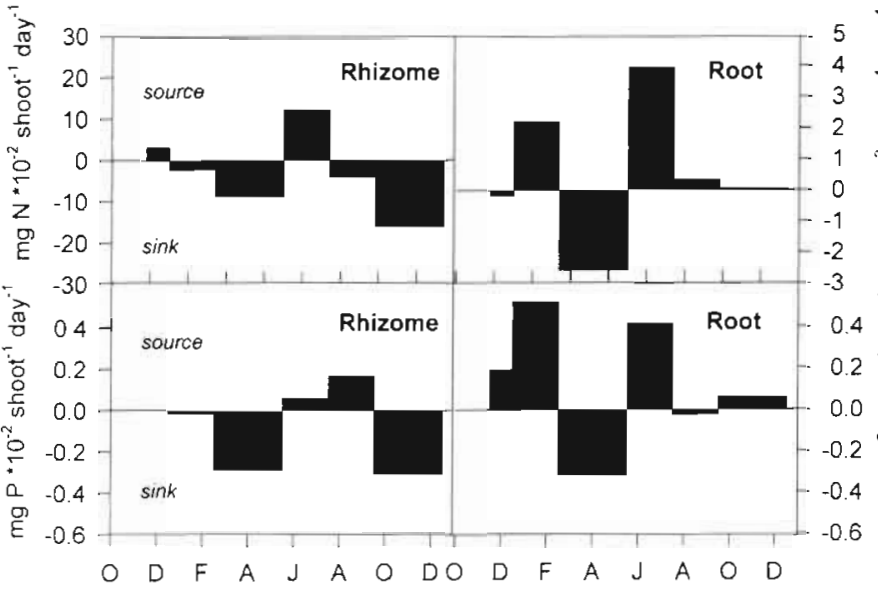

Fig. 6. Time course of nutrient (nitrogen and phosphorus) translocation from/ to rhizomes and roots

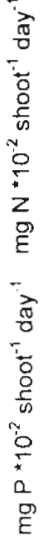

The buffering capacity of rhizomes and roots suggests that the rhizomes acted as a source of nutrients during summer and as a sink during the rest of the year (Fig. 6). Roots presented a less clear pattern with 2 periods acting as a source (winter and summer) and an intermediate period acting as a sink (spring).

\section{DISCUSSION}

Nutrient concentration in each Posidonia oceanica age class followed a seasonal pattern similar to that observed in whole shoots (Alcoverro et al. 1995). This pattern of variability in nitrogen concentration has also been observed in Zostera marina (Pedersen \& Borum 1993). Some authors have suggested that the seasonality found in shoot nutrient concentration (higher in winter, lower in summer) was induced by the seasonality in shoot age composition (Pellikaan 1984, Pirc \& Wollenweber 1988). However, our results showed a clear seasonal pattern in nutrient concentrations (non-significant interactions in Table 1, except for phosphorus) across tissue age classes, with a clear accumulation of nutrients during winter for all the age classes.

With this new methodological approach that contemplates age classes instead of leaves for obtaining the nutrient curves, we are able to improve our nutrient Ietranslocation estimates. Consequently we can now assess annual values of retranslocation $140 \% \mathrm{~N}$ and $59 \%$ P) that are more precise and unequivocally higher than those obtained in previous works $(20 \% \mathrm{~N}$ and 18\% $\mathrm{P}$ in Alcoverro et al. 1997).

Nutrient balance studies in terrestrial plants have evidenced the importance of the seasonal nutrient recycling (e.g. Jonasson \& Chapin 1985). Retranslocation of nutrients in seagrasses also varies seasonally, at least in temperate seagrass species (Pedersen \& Borum 1993, this work). This is consistent with the seasonal uncoupling of growth and nutrient availability (Thom \& Albright 1990 , Alcoverro et al. 1995); therefore this has to be taken into account when we infer retranslocation values from short-time sampling (e.g. Patriquin 1972, Harrison \& Mann 1975, Borum et al. 1989, Stapel \& Hemminga 1997).

Along the seasonal growth cycle of Posidonia oceanica, 3 strategies are used to fit the nutrient demand of the plant: (1) acquisition from external sources (i.e the water column or the sediment pore water), (2) re-use of internal pools, which potentially include nutrient retranslocation from old leaves and nutrient retranslocation from other organs (roots and rhizomes), and (3) use of nutrients stored in the 
leaves themselves. During winter, nutrients are generally taken up from the external medium in excess of that of carbon, and the nutrient concentration in leaves increases (Alcoverro et al. 1995, this work). From spring to the end of summer, nutrients are exhausted in the sediment pore water and in the water column, (Ballesteros 1989, Alcoverro et al. 1995, Vidondo \& Duarte 1995, Cebrián et al. 1996), while leaf growth attains its maximum (Alcoverro et al. 1995, this work). The nutrient demands are then met by the use of internal pools, among which the process of nutrient reclamation from old leaves may be important. However, the incorporation of carbon is still in excess of that of nutrients, with a concomitant decrease in nutrient concentration, eventually leading to nutrient shortage. This pattern is consistent with previous findings at the Medes Island site, where $P$, oceanica responded to experimental nutrient addition in spring and summer, while no response was observed in winter-fall (Alcoverro et al. 1997).

It should be acknowledged that the method used has a serious drawback, in the sense that a nutrient mass balance does not permit one to discriminate between nutrient recovery and nutrient release to the external medium (leaching). Moreover, direct experimental measurements would have been needed to elucidate in detail which part of the nutrient decrease in old leaves would correspond to leaching. Hence the reported values of retranslocation should be viewed as maximum potential values. Nevertheless we must remember that direct measurements of leaching have been proved to be very complex, especially in plants such as Posidonia oceanica that grow with difficulty in a laboratory. The few reports that have measured leaching by direct methods state the marginal importance of this process in the nutrient budget of seagrasses. In Zostera marina, presumably the better known case, leaching never exceeds $10 \%$ of the total nutrient losses (Borum et al. 1989, Pedersen \& Borum 1992). Hence, we conclude that the proposed retranslocation rates, although presumably overestimated, should be very close to the real values.

Other plant parts can also contribute to the supply of nutrients during spring-summer, but their role is, apparently, only minor. In the case of the leaf bases or petioles, seasonal changes in nutrient concentrations were similar to those found in the leaves. Lower values have been reported in dead petioles relative to living ones (see Manzanera et al. 1998), indicating that possible nutrient reclamation can also occur on these organs. However, their contribution to the overall nutrient budget should be modest, due to their low biomass relative to leaves and their low nutrient concentration. The seasonal changes in nutrient concentra- tions of rhizomes and roots were less clear and even if they act as a nutrient source in early summer (Fig. 6) their contribution to the overall nutrient mass balance seems relatively small. In any case, the role of rhizomes and roots as short-time or long-time nutrient buffers remains to be examined in detail.

Our data suggest that retranslocation of nutrients in Posidonia oceanica constitutes a mechanism for optimizing nutrient use, which becomes important during times of nutrient shortage. This is also the case in other seagrasses and in terrestrial plants (e.g. Chapin \& Bloom 1976, Jonasson \& Chapin 1985, Chapin et al. 1986, Pedersen \& Borum 1993). However, in general terms, relationships (across species) between leaf nutrient status and leaf nutrient retranslocation capacities have shown to be very weak in most terrestrial plants and seagrasses (Del Arco et al. 1991, Aerts 1996, Stapel \& Hemminga 1997). Other plant features, such as the increase of leaf longevity, seem to be better correlated with nutrient availability, and constitute a significant adaptation for increasing the efficiency in the use of nutrients (Escudero et al. 1992).

Based on a general nutrient budget at the ecosystem level, Mateo \& Romero (1997) proposed that nutrient losses were relatively small in Posidonia oceanica meadows, and that most phosphorus and, probably, most nitrogen (i.e. 80 to $90 \%$ ) were recycled within the system. The data presented support this notion, and indicate that retranslocation could be one of the main mechanisms by which nutrient conservation is accomplished. In effect, retranslocation represented $40 \%$ of the requirements for nitrogen and $59 \%$ for phosphorus in $P$. oceanica on an annual basis. These values are higher than the average values of nutrient retranslocation reported for seagrasses $115 \%$ for nitrogen and $21 \%$ for phosphorus, Stapel \& Hemminga 1997) and closer to those found in terrestrial plants (Jonasson \& Chapin 1985, Chapin \& Shaver 1988, Escudero et al. 1992, Reich et al. 1995). A tentative hypothesis to explain this is the long lifespan of $P$. oceanica leaves (around $150 \mathrm{~d}$ on average, maximum of $300 \mathrm{~d}$ : Romero 1989b), higher than those of most seagrass species (Duarte 1991). This persistence of leaves allows a more efficient nutrient recovery than in the case of an early abscission (Escudero et al. 1992). In addition, leaf longevity also implies a greater residence time of nutrients in the plant, and a reduction of nutrient demands.

Species with long-lived leaves like $P$. oceanica may minimize their dependence upon external nutrients through an effective internal retranslocation and conservation of nutrients. This can contribute to the understanding of why this species has colonized vast areas under nutrient-poor conditions. 
Acknowledgements. This work was supported by grant STEP-0063-C of the ECC. We thank Xavier de Pedro, Miguel Ángel Mateo, Marta Pérez and Olga Invers for their help in the field. C, N and P analyses were performed in the 'Serveis Científico-Tècnics de la Universitat de Barcelona'. We also thank 3 anonymous referees whose criticisms considerably improved the quality of the manuscript.

\section{LITERATURE CITED}

Aerts R (1996) Nutrient resorption from senescing leaves of perennials: are there general patterns? J Ecol 84: $597-608$

Alcoverro T, Duarte CM, Romero J (1995) Annual growth dynamics of Posidonia oceanica: contribution of largescale versus local factors to seasonality. Mar Ecol Prog Ser 120:203-210

Alcoverro T, Romero J, Duarte CM, López NI (1997) Special and temporal variations in limitation of seagrass Posidonia oceanica growth in the NW Mediterranean. Mar Ecol Prog Ser 146:155-161

Ballesteros E (1989) Production of seaweeds in Northwestern Mediterranean marine communities: its relation with environmental factors. In: Ros JD (ed) Topics in marine biology. Sci Mar (Spec Issue) 53(2-3):357-364

Bay D (1978) Etude 'in situ' de la production primaire d'un herbier de Posidonies (Posidonia oceanica (L.) Delile) de la Baie de Calvi-Corse. PhD thesis. Université de Liège

Borum J, Murray L, Kemp MW (1989) Aspects of nitrogen acquisition and conservation in eelgrass plants. Aquat Bot 35:289-300

Buia MC, Zupo V, Mazzella L (1992) Primary production and growth dynamics of Posidonia oceanica. PSZN I: Mar Ecol $13(1): 1-15$

Cebrián J, Duarte CM, Pascual J (1996) Marine climate on the Costa Brava (northwest Mediterranean) littoral. Publ Inst Esp Oceanogr 22:9-21

Cebrián J, Duarte CM, Marbà N, Enriquez S (1997) Magnitude and fate of the production of four co-occurring Western Mediterranean seagrass species. Mar Ecol Prog Ser $155: 29-44$

Chapin FS III, Bloom AJ (1976) Phosphate absorption: adaptation of tundra graminoids to a low temperature, low phosphorus environment. Oikos 26:111-121

Chapin FS III, Shaver GR (1988) Differences in carbon and nutrient fractions among arctic growth forms. Oecologia 77:506-514

Chapin FS III, Shaver GR, Kedrowski RA (1986) Environmental controls over carbon, nitrogen, and phosphorus fractions in Eriophorum vaginatum in Alaskan tussock tundra. $\mathrm{J}$ Ecol 74:167-195

Del Arco JM, Escudero A, Garrido MV (1991) Effects of site characteristics on nitrogen retranslocation from senescing leaves. Ecology 72(2):701-708

Duarte CM (1990) Seagrass nutrient content. Mar Ecol Prog Ser 67:201-207

Duarte CM (1991) Allometric scaling of seagrass form and productivity. Mar Ecol Prog Ser 77:289-300

Escudero A, Del Arco JM, Sanz IC. Ayala J (1992) Effects of leaf longevity and retranslocation eficiency on the retention time of nutrients in the leaf biomass of different woody species. Oecologia $90: 80-87$

Harrison PG, Mann KH (1975) Chemical changes during the seasonal cycle of growth and decay in eelgrass (Zostera marina) on the Atlantic coast off Canada. J Fish Res Board Can 321:615-621
Hemminga MA, Harrison PG, Vanlent F (1991) The balance of nutrient losses and gains in seagrass meadows. Mar Ecol Prog Ser 71:85-96

Ivanoff A (1977) Oceanic absorption of solar energy. In: Kraus EB (ed) Modelling and prediction of the upper layers of the ocean. Pergamon Press, Oxford, p 47-71

Jonasson S, Chapin FS III (1985) Significance of sequential leaf development for nutrient balance of the cotton sedge, Eriophorum vaginatum L. Oecologia 67:511-518

Manzanera M, Alcoverro T, Romero J (1998) The role of the remnant leaf sheaths (scales) attached to the Posidonia oceanica (L.) Delile rhizomes. J Exp Mar Biol Ecol 223 $257-270$

Mateo MA, Romero J (1997) Detritus dynamics in the seagrass Posidonia oceanica: elements for an ecosystem carbon and nutrient budget. Mar Ecol Prog Ser 151:43-53

Mateo MA, Sabaté S (1993) Wet digestion of vegetable tissue using a domestic microwave oven. Anal Chem 279:273-279

Patriquin DG (1972) The origin of nitrogen and phosphorus for growth of the marine angiosperm Thalassia testudinum. Mar Biol 15:35-46

Pedersen MF, Borum J (1992) Nitrogen dynamics of eelgrass Zostera marina during a late summer period of high growth and low nutrient availability. Mar Ecol Prog Ser 80:65-73

Pedersen MF, Borum J (1993) An annual nitrogen budget for a seagrass Zostera marina population. Mar Ecol Prog Ser 101:180-177

Pellegrini M (1971) Contribution a l'étude biochimique des phanerogames marines. Variations saisonnieres des acides amines protidiques des rhizomes de Posidonia oceanica Delile. Thalassia Jugos1 7(1):241-245

Pellikaan GC (1984) Laboratory experiments on eelgrass (Zostera marina L.) decomposition. Neth J Sea Res 18: $360-383$

Pérez-Llorens JL, Niell FX (1989) Emergence and submergence effects on the distributional pattern and exchange of phosphorus in the seagrass Zostera noltii Hornem. In Ros JD (ed) Topics in marine biology. Sci Mar (Spec Issue) 53:497-503

Pirc H (1985) Growth dynamics in Posidonia oceanica (L.) Delile. PSZN I: Mar Ecol 6(2):141-165

Pirc H, Wollenweber B (1988) Seasonal changes in nitrogen, free amino acids, and $\mathrm{C} / \mathrm{N}$ ratio in Mediterranean seagrasses. PSZN I: Mar Ecol 9:167-179

Poole HH, Atkins RG (1929) Photo-electric measurement of submarine illumination throughout the year. J Mar Biol Assoc UK 16:297-324

Reich PB, Ellsworth DS, Uhl C (1995) Leaf carbon and nutrient assimilation and conservation in species of differing successional status in an oligotrophic Amazonian forest. Funct Ecol 9:65-76

Romero J (1989a) Primary production of Posidonia oceanica beds in the Medes Islands (Girona, NE Spain). In: Boudouresque $C F$, Meinesz A, Fresi E, Gravez V (eds) International workshop on Posidonia beds. GIS Posidonie, Marseille, p 85-91

Romero J (1989b) Seasonal pattern of Posidonia oceanica production: growth, age and renewal of leaves. In: Boudouresque CF, Meinesz A, Fresi E, Gravez V (eds) International workshop on Pusidonia beds. GIS Posidonie, Marseille, p 63-68

Shaver GR, Melillo JM (1984) Nutrient budgets of marsh plants: efficiency concepts and relation to availability. Ecology 65:1491-1510

Sokal RR, Rohlf FJ (1981) Biometry. Freeman \& Co, New York

Stapel J, Hemminga MA (1997) Nutrient resorption from seagrass leaves. Mar Biol 128:197-206 
Thayer GW, Engel DW, LaCroix MW (1977) Seasonal changes in the nutritive quality of living, dead and detrital fractions of Zostera Marina L. J Exp Mar Biol Ecol 30:109-127

Thom RM, Albright RG (1990) Dynamics of benthic vegetation standing-stock, irradiance, and water properties in central Puget Sound. Mar Biol 104:129-141

Tukey HBJ (1970) The leaching of substances from plants. Annu Rev Plant Physiol 21:305-324

Vidondo B, Duarte CM (1995) Seasonal growth of Codium bursa, a slow-growing Mediterranean macroalga: in situ experimental evidence of nutrient limitation. Mar Ecol Prog Ser 123:185-191

Editorial responsibility: Otto Kinne (Editor),

Oldendorf/Luhe, Germany
Vitousek PM, Gosz JR, Grier CC, Melillo JM, Reiners WA (1982) A comparative analysis of potential nitrification and nitrate mobility in forest ecosystems. Ecol Monogr 52: $155-177$

Walker DI, Lukatelich RJ, Bastian G, McComb AJ (1989) Effect of boat moorings on seagrass beds near Perth, Western Australia. Aquat Bot 36:69-77

Weinberg S (1976) Submarine daylight and ecology. Mar Biol $37: 292-304$

Zieman JC (1974) Methods for the study of the growth and production of turtle grass, Thalassia testudinum König Aquaculture 4:139-143

Submitted: August 14, 1998, Accepted: September 16, 1999 Proofs received from author(s): February 25, 2000 